\title{
Safety and Precautionary Measures for Staff and Students During the Covid 19 Pandemic: A Malawian College of Health Sciences Case
}

\author{
D Nyirenda* \\ Department of Radiography, Malawi College of Health Sciences, Malawi
}

*Corresponding author: D Nyirenda, department of Radiography, Faculty of Medical Sciences, Malawi College of Health Sciences, Lilongwe, Malawi.

To Cite This Article: D Nyirenda. Safety and Precautionary Measures for Staff and Students During the Covid 19 Pandemic: A Malawian College of Health Sciences Case. 2020 - 11(1). AJBSR.MS.ID.001598. DOI: 10.34297/AJBSR.2020.11.001598.

Received: 䟧 November 23, 2020; Published: 眥 December 03, 2020

\section{Introduction}

The coronavirus (Covid-19) pandemic is exacting a huge toll on individuals, families, communities and societies across the world [1]. Furthermore, the pandemic has changed the lives of individuals, families, communities and societies globally (Inter-Agency Standing Committee; 2020). The protection of students, staff and educational facilities is particularly important during Covid-19 pandemic [2]. According to the Centre for Health protection [3], schools/ colleges need to develop precautionary measures to minimize the risk of contracting and spreading Covid-19 after class resumption. Safety measures taken by schools/colleges can prevent the entry and spread of Covid 19 by students and staff who may have been exposed to the virus [1]. As of 24th March 2020, confirmed global COVID 19 incidences were 39827, with a reported death toll of 1722. Among reported cases Africa alone confirmed 315, with 3 reported deaths [1]. On 20 March 2020, Covid-19 was declared a national disaster in Malawi and on 2 April 2020 Malawi registered the first cases of COVID-19 [4].

As a way of averting COVID 19 - related effects Malawi adopted certain measures such as closure of schools and colleges following the directive by the President of the Republic of Malawi. As of 20th May 2020, Malawi had cumulatively recorded 76 cases including
3 deaths [5]. Therefore, while Covid 19 continues to spread, it is important that authorities take action to prevent further transmission, reduce the impacts of the outbreak and support control measures [1]. Sets of recommendations for staff and students at a Malawian College of Health Sciences was therefore developed as a precautionary measure to protect them from the Covid-19 pandemic. The sets of recommendations shall provide guidance on how staff and students should protect themselves from Covid-19 pandemic [6].

\section{Procedure and Quality of Data}

The idea to develop the sets of recommendations was necessitated by the fact that there were no sets of recommendations specifically for the staff and students at the Malawian College to guide them during the Covid-19 pandemic. The content of these recommendations was based on a literature review following the review of Guidance for Covid-19 Prevention and Control in Schools/ Colleges by [2] as well as review of Malawi, Ministry of Education [7] Guidelines for Schools in Malawi on Prevention and Management of Covid-19. Face validity of the recommendations was ensured by requesting review of the recommendations by a 28-member panel which constitutes members of Campus Management team. 


\section{Sets of Recommendations (Table 1)}

Table 1: Sets of recommendations.

\begin{tabular}{|c|c|c|}
\hline Set of recommendations & Objectives & Recommendations \\
\hline \multirow{6}{*}{$\begin{array}{l}\text { Entry into and exit from } \\
\text { college premises }\end{array}$} & \multirow{6}{*}{$\begin{array}{l}\text { To control } \\
\text { the spread } \\
\text { ofCovid-19 } \\
\text { virus into } \\
\text { the College } \\
\text { premises }\end{array}$} & $\begin{array}{l}\text { Ensure that all entry points to the college campus have hand hygiene equipment such as soap and } \\
\text { water buckets. }\end{array}$ \\
\hline & & Everyone entering the college premises should be screened. \\
\hline & & The College should ensure restriction of visitors to the campus. \\
\hline & & $\begin{array}{l}\text { All staff and students are required to use the main gate entrance into and exit from the campus prem- } \\
\text { ises. }\end{array}$ \\
\hline & & Chlorinated doormats and/disinfecting booths shall be placed on designated points. \\
\hline & & $\begin{array}{l}\text { All worship services for students shall be conducted at the campus, there shall be no intercollege } \\
\text { worship prayers. }\end{array}$ \\
\hline \multirow{12}{*}{$\begin{array}{l}\text { Safety of classrooms, labo- } \\
\text { ratories/skill laboratories, } \\
\text { library, common and confer- } \\
\text { ence rooms }\end{array}$} & \multirow{12}{*}{$\begin{array}{l}\text { To ensure } \\
\text { that the } \\
\text { classrooms, } \\
\text { laboratories, } \\
\text { library com- } \\
\text { mon and con- } \\
\text { ference rooms } \\
\text { are free from } \\
\text { Covid-19. }\end{array}$} & Each student shall be screened at entry to the classroom, laboratory, common and conference rooms. \\
\hline & & $\begin{array}{l}\text { All students shall be required to put on a mask whenever in the classroom, laboratory, common and } \\
\text { conference rooms. }\end{array}$ \\
\hline & & Post maximum occupancy on the door of each room to accommodate appropriate physical distancing. \\
\hline & & For Library sessions, a maximum of 30 students per session and 40 students per classroom session. \\
\hline & & Provide sanitizing supplies for students to clean their areas before and after use. \\
\hline & & Provide hand washing facilities including running water, soap and/or hand sanitizer at all entrances. \\
\hline & & $\begin{array}{c}\text { Restrict or limit the number of users per time in the library to keep social distance and disinfect the } \\
\text { library after each group. }\end{array}$ \\
\hline & & Consider allowing reserved books to be used even outside the library. \\
\hline & & Strictly set time limit for how long a student must use the library. \\
\hline & & Create multiple sections or shifts for classes to reduce congestion. \\
\hline & & Ensure that students are provided with adequate personal protective equipment for clinical practice. \\
\hline & & Develop simulations of clinical scenarios for students to practice clinical skills. \\
\hline \multirow{11}{*}{$\begin{array}{l}\text { Safety of students' halls of } \\
\text { residents }\end{array}$} & \multirow{11}{*}{$\begin{array}{l}\text { To prevent } \\
\text { the outbreak } \\
\text { and spread of } \\
\text { Covid-19 pan- } \\
\text { demic in the } \\
\text { students' halls } \\
\text { of residents }\end{array}$} & Ensure that physical distancing of 1-2 meters is maintained between students' beds. \\
\hline & & Ensure that the bathrooms are cleaned with appropriately and disinfected every day. \\
\hline & & Encourage students to wear face masks in all common places. \\
\hline & & Restrict events and social activities as per current physical distancing guidance. \\
\hline & & Re-arrange seating in common areas to ensure proper physical distancing. \\
\hline & & Restrict access by non-resident students, outside guests, non-resident staff and others. \\
\hline & & Widely post information in common areas about Covid-19 prevention. \\
\hline & & $\begin{array}{l}\text { Frequent reminders of proper hand hygiene (verbally, posters, videos) with hand sanitizer widely } \\
\qquad \text { available in common areas and rooms. }\end{array}$ \\
\hline & & Enhance cleaning of all common areas and high touch surfaces. \\
\hline & & $\begin{array}{l}\text { Where students are residing outside campus, they need to adhere to guidelines from local and nation- } \\
\text { al authorities. }\end{array}$ \\
\hline & & $\begin{array}{l}\text { College authorities should notify all non-residential students about preventive measures so that they } \\
\text { inform their landlords who are privately accommodating students off campus to observe the Covid-19 } \\
\text { preventive guidelines. }\end{array}$ \\
\hline \multirow{6}{*}{ Safety of catering services } & \multirow{6}{*}{$\begin{array}{l}\text { To ensure that } \\
\text { the catering } \\
\text { is free from } \\
\text { outbreak and } \\
\text { spread of } \\
\text { Covid-19 }\end{array}$} & $\begin{array}{l}\text { Access control: once the target number is reached, patrons should only allow other students to enter } \\
\text { when others are leaving. }\end{array}$ \\
\hline & & $\begin{array}{l}\text { Cohort dining: establishing dining times by admitting a specific group of customers/diners at a time } \\
\text { e.g. } 100 \text { students in each group. }\end{array}$ \\
\hline & & Physically spaced (1-2metres) floor markers for waiting lines outside and inside the cafeteria. \\
\hline & & Appropriately spaced and limited numbers of tables and chairs per table. \\
\hline & & $\begin{array}{c}\text { Extend meals time from } 11 \text { am to } 2 \mathrm{pm} \text { for lunch and } 6 \text { to } 9 \mathrm{pm} \text { for supper to reduce congestion in } \\
\text { cafeterias. }\end{array}$ \\
\hline & & Provide take away meals including arranging food delivery to students in isolation or quarantine. \\
\hline
\end{tabular}




\begin{tabular}{|c|c|c|}
\hline \multirow{4}{*}{ Safety relating to vending } & \multirow{4}{*}{$\begin{array}{l}\text { To prevent } \\
\text { students from } \\
\text { contracting } \\
\text { Covid-19 from } \\
\text { vendors. }\end{array}$} & Buying of food items from kiosks outside the campus shall be prohibited. \\
\hline & & A representative of each group of students shall be assigned to buy food on behalf of other students. \\
\hline & & $\begin{array}{l}\text { The Staff College kitchen shall be entrusted with selling other food items to students at subsidized } \\
\text { cost to control mobility of students outside the campus. }\end{array}$ \\
\hline & & $\begin{array}{l}\text { Students coming from practical settings are discouraged from buying items from vendors outside the } \\
\text { campus until such a time when they change their clothes, wash and sanitize. }\end{array}$ \\
\hline \multirow{6}{*}{$\begin{array}{l}\text { Isolation and quarantine } \\
\text { rooms }\end{array}$} & \multirow{6}{*}{$\begin{array}{c}\text { To prevent } \\
\text { the spread of } \\
\text { Covid-19 from } \\
\text { one student to } \\
\text { another. }\end{array}$} & All Covid-19 suspects shall be screened, tested and quarantined at campus tents. \\
\hline & & Suspects that shall test positive shall be referred to the local hospital for further management. \\
\hline & & $\begin{array}{l}\text { Every student who is sick should immediately report to the Health and Wellness Committee who shall } \\
\text { assign clinician to assess the student. }\end{array}$ \\
\hline & & $\begin{array}{l}\text { Every member of staff who has fever, cough and difficulty breathing shall be required to call a toll-free } \\
\text { number for guidance. }\end{array}$ \\
\hline & & $\begin{array}{l}\text { Every member of staff who has flu-like symptoms shall be allowed to work from home or should not } \\
\text { report to work. }\end{array}$ \\
\hline & & $\begin{array}{l}\text { If a member of staff has developed flu-like symptoms while at work, he or she should report to the } \\
\text { Health and wellness committee for screening. }\end{array}$ \\
\hline
\end{tabular}

\section{Conclusion}

The recommendations aim to enhance Covid-19 safety and precautionary measures. They were developed for staff and students at a Malawian College of Health Sciences. The recommendations may require to be further reviewed by experts for further validation. Correct implementation of the sets of recommendations shall ensure that there is a Covid-19 free environment at the college. However, for successful implementation of the set of recommendations the college shall need resources such as soap, aprons, buckets, bins, basins, paper rolls, face masks, gloves, chlorine, infrared thermometer, door mats, hand sanitisers, face shields for staff and information, communication as well as educational materials. Furthermore, management, staff and student commitments are also crucial for successful implementation of the sets of recommendations.

\section{References}

1. (2020) WHO, Covid-19 Strategy Update, Geneva, Switzerland.

2. (2020) UNICEF, Guidance for Covid-19 Prevention and Control in Schools, UNICEF New York, USA.

3. (2020) Health Advice to Schools for the Prevention of Coronavirus disease (Covid-19), Centre for Health Protection Hong Kong.

4. (2020) Malawi Covid-19 Daily Situation Report. Public Health Institute of Malawi Epidemiology Unit, Lilongwe, Malawi.

5. (2020) Malawi Covid-19 Emergency Response and Health Systems Preparedness. Malawi Ministry of Health Lilongwe, Malawi.

6. (2020) Public Health and Social Measures for Covid 19 Preparedness and Response in Low Capacity and Humanitarian Settings. Inter-Agency Standing Committee Switzerland.

7. (2020) Guidelines for Schools in Malawi on Prevention and Management of Covid-19. Malawi Ministry of Education Lilongwe, Malawi. 